\title{
TECHNICAL EFFICIENCY IN ORGANIC AND CONVENTIONAL AGRICULTURE - A GENDER COMPARISON
}

\author{
Justice G. DJOKOTO * 1,2, Victor OWUSU ${ }^{2}$, Dadson AWUNYO-VITOR ${ }^{2}$
}

\author{
Address: \\ ${ }^{1}$ Agribusiness Management Department, Central University, Accra, Ghana. \\ ${ }^{2}$ Department of Agricultural Economics, Agribusiness and Extension, Kwame Nkrumah University of Science and \\ technology, Kumasi, Ghana. \\ * Corresponding author e-mail: dgameli2002@gmail.com
}

\begin{abstract}
This article contributes to the pertinent literature by providing a gender perspective to organic-conventional technical efficiency comparative studies and to the debate on technical efficiency of organic and conventional agriculture. Data from 280 organic and 378 conventional cocoa farm from Suhum area in Ghana; segregated into 101 females and 557 males, were analysed. Using separate frontiers, females were found to be more technically efficient than males irrespective of technology; conventional or organic, although males tended to be more productive. Increased access to productive inputs to females is necessary to increase their participation in organic cocoa production and further enhance efficiency.
\end{abstract}

Keywords: Cocoa, conventional agriculture, gender, Ghana, organic agriculture, Suhum. JEL: D24, J16

\section{INTRODUCTION}

The difference between the observed output and what is attainable is technical inefficiency (Farrell, 1957). The increase in technical inefficiency provides opportunity for farmers to increase output using the same level of resources (Beltrán-Esteve and Reig-Martínez, 2014). The need to increase efficiency have attracted the attention of both conventional and organic agricultural production. The focus of comparative studies on conventional and organic efficiency studies have been to show which is more technically efficient. Tzouvelekas $\boldsymbol{e t}$ al. (2001), Arandia and Aldanondo-Ochoa (2008), Oude Lansink et al. (2002) and Poudel et al. (2011), noted that, conventional agriculture is relatively more inefficient than organic agriculture. On the contrary, Charyulu and Biswas (2010), Karagiannias et al. (2006), Madau (2007) and Tiedemann and LataczLohmann (2012) concluded that, organic agriculture is more technical inefficient than conventional agriculture. Mayen et al. (2010) however intimated that, measured against the appropriate technology, organic and conventional agriculture (dairy) did not show any significant difference in technical inefficiency.

Aside of this technology dimension to organic and conventional technical efficiency debate, UNDP introduced a gender perspective to organic agriculture. That, organic agriculture requires managing the agroecosystem as an autonomous system, based on the primary production capacity of the soil under local climatic conditions. This implies treating the system, on any scale, as a living organism supporting its own vital potential for biomass and animal production. The biological mechanisms for mineral balancing, soil improvement and pest control are part of the system (UNDP, 1992). Farmers of both sexes are involved on equal terms, with their families and rural communities, which are an integral part of this agroecosystem (UNDP, 1992). Therefore, does the equal involvement of both sexes translate into equal adoption and efficiency of organic production? This question is addressed using data on male and female organic and conventional cocoa producers in Suhum area in Ghana.

Djokoto (2015) and Lakner and Breustedt (2015, 2016) have documented additional technical efficiency studies that have compared organic and conventional agriculture. In all these, those that addressed gender, used it as an inefficiency effect in the second stage regression. In this article, separate frontiers were estimated for each gender category whilst contributing to the technical efficiency debate on organic and conventional agriculture.

Overview of organic agriculture is presented next, followed by the data and methods. The presentation of results and discussion precedes the conclusion and recommendations.

\section{ORGANIC AND CONVENTIONAL AGRICULTURE}

\section{Principles of organic agriculture}

Organic farming is an especially environmentally friendly farming style that aims to run the farm as an integrated system (Mader et al., 2002; Best, 2010). Organic farming is governed by rules, the generality of which has been established by the International Federation of Organic Agriculture Movements (IFOAM). The most important internationally accepted standards, 
consisting of a multitude of rules on cultivation, pest and weed control, and animal husbandry have been set out in IFOAM (2014). This is based on four principles, namely; health, ecology, fairness and care (IFOAM, undated).

The principle of health posits that, organic agriculture should sustain and enhance the health of soil, plant, animal, human and planet as one and indivisible. The key characteristics of health are immunity, resilience and regeneration. Health in this context, is not simply the absence of illness, but the maintenance of physical, mental, social (WHO, 2003) and ecological well-being.

Production is to be based on ecological processes, and recycling. This is the principle of ecology. Organic operators must therefore work with the living systems, emulate them and help sustain them. Nourishment and well-being are achieved through the ecology of the specific production environment. Apart from organic farming, pastoral and wild harvest systems should fit the cycles and ecological balances in nature. Recycling (through reuse), efficient management of materials and energy, in order to maintain and improve environmental quality and conserve resources are encouraged.

Fairness is characterised by equity, respect, justice and stewardship of the shared world, both among people and in their relations to other living beings. The goals of fairness are: 1. Produce sufficient supply of good quality food and other products. 2. Build on relationships that ensure fairness with regard to the common environment and life opportunities. 3. Animals should be provided with the conditions and opportunities of life that accord with their physiology, natural behaviour and well-being. 4. Natural and environmental resources that are used for production and consumption should be managed in a way that is socially and ecologically just and should be held in trust for future generations.

In organic agriculture, precaution and responsibility are the key concerns in management, development and technology choices. This principle of care emphasises that, whilst science is a necessary condition to ensure that organic agriculture is healthy, safe and ecologically sound; practical experience, accumulated wisdom and traditional and indigenous knowledge, which offer time tested valid solutions are sufficient conditions for organic production. Organic agriculture should prevent significant risks by adopting appropriate technologies. Decisions should reflect the values and needs of all who might be affected, through transparent and participatory processes. The principle of care enjoins practitioners to manage resources in a precautionary and responsible manner to protect the health and well-being of current and future generations and the environment.

\section{Organic certification}

Organic certification is based on a pledge by certificated farmers (operators) to comply by some standards. These standards are produced and enforced by both private institutions and governments. Some countries in Europe such as France and Germany had national standards. The UK Soil Association (UKSA) also has standards. The European Union standards are however in force, although UKSA still operates independently of the EU standards.
Australia, Canada, Japan and the United States of America (US) also have their national standards. However, there are varying levels of recognition of certification (standards). For the purpose of this article, organic practices are recognised so long as they are certified by a national or international organic certifying body.

The process of certification starts with an application for certification. The applicant completes a questionnaire. Where the land has ever been cultivated, applicants are granted in-conversion status. When this period (usually two years) elapses, full organic status is granted. After the first inspection, annually, there is inspection to ensure compliance. Prior to application, the farmer must study the appropriate organic standards. Farmers are expected to ensure farm facilities and production methods conform to the standards. Extensive documentation such as farm history and current set-up, and usually includes results of soil and water tests are required. To enhance subsequent documentation, record-keeping forms an integral part of organic agriculture. The record-keeping involves written, day-to-day farming and marketing records and covers all activities which must be available for inspection at any time. A written annual production plan would usually be submitted. This contains everything from seed to sale: seed sources, field and crop locations, fertiliser application and pest control activities, harvest methods and storage locations among others. This process of certification makes organic a process claim rather than a product claim (FAO, 1999).

\section{Organic and conventional cocoa production}

The employment of these principles has led to some key practices in organic cocoa production (Table 1, column 3 ). These contrasts with conventional production practices that differ based on planting, weed, pest and disease control of cocoa (Table 1, column 2).

\section{DATA AND METHODS}

\section{Research area}

As at 2014, organic cocoa production in Ghana was only located in the Suhum-Craboa-Coalter district of the Eastern Region of Ghana. The district is bounded on the north by Kwabibirem, on the south west by West Akim, on the south east by Akwapim North and South districts and on the east by East Akim and New Juaben Municipality. According to YGL, (2008), the total land area is about $850 \mathrm{~km}^{2}$ with $20 \%$ of this area under cocoa cultivation contributing more than 500 metric tonnes of beans. About 600 ha of land was under organic cocoa by 2003. Since then, significant progress has been made (Ayenor et al., 2004). More than 10,000 ha are under organic cocoa cultivation made up of more than 1,000 organic certified farms (YGL, 2013).

\section{Data collection}

In order to obtain farmers with similar operating environment, the population of conventional cocoa growers is defined to be in the Suhum Cocoa district. 
Table 1. Conventional and organic cocoa cultivation practices ${ }^{1}$

\begin{tabular}{|c|c|c|}
\hline Practice & Conventional practices ${ }^{2}$ & Organic practices ${ }^{3}$ \\
\hline Planting & $\begin{array}{l}\text { Spacing: } 3 \mathrm{~m} \times 3 \mathrm{~m} \text {. Seedlings from clean nurseries or } \\
\text { planting at stake }\end{array}$ & $\begin{array}{l}\text { Spacing: } 3 \mathrm{~m} \times 3 \mathrm{~m} . \text { seedlings from only organic } \\
\text { nurseries }\end{array}$ \\
\hline Weed control & $\begin{array}{l}\text { Manual weed control, use of cover crops and recommended } \\
\text { chemicals. }\end{array}$ & $\begin{array}{l}\text { Weed regularly manually. Use cover crops. No } \\
\text { chemical weed control. }\end{array}$ \\
\hline $\begin{array}{l}\text { Pests and } \\
\text { Diseases }\end{array}$ & $\begin{array}{l}\text { Remove mistletoes, dead branches and black pods. } \\
\text { Collect and burn away from the farm diseased pods once a }\end{array}$ & $\begin{array}{l}\text { Remove mistletoes, dead branches and black } \\
\text { pods. }\end{array}$ \\
\hline control & $\begin{array}{l}\text { week to prevent spread of black pod disease. When } \\
\text { necessary to bury on the field, bury } 60 \mathrm{~cm} \text { deep. Remove } \\
\text { pods with even small sign of black pod attack. Apply } \\
\text { recommended chemicals. Dosage } 85 \mathrm{ml} / \mathrm{ha} \text { to } 500 \mathrm{ml} / \mathrm{ha} \\
\text { depending on pesticide. }\end{array}$ & $\begin{array}{l}\text { Collect and burn away from the farm diseased } \\
\text { pods once a week to prevent spread of black pod } \\
\text { disease. When necessary to bury on the field, } \\
\text { bury } 60 \mathrm{~cm} \text { deep. Remove pods with even small } \\
\text { sign of black pod attack. }\end{array}$ \\
\hline & Wear protective clothing. & $\begin{array}{l}\text { Spray with neem tree extract when sanitation } \\
\text { practices are inadequate. }\end{array}$ \\
\hline & & Apply 401 trs $/ \mathrm{ac}=3$ mistblowers/acre. \\
\hline & & $\begin{array}{l}\text { Wear protective clothing. } \\
\text { Other permitted products can be used. }\end{array}$ \\
\hline $\begin{array}{l}\text { Fertility } \\
\text { management }\end{array}$ & $\begin{array}{l}\text { Apply NPK fertilisers such as Asaase Wura and Cocofeed. } \\
\text { Others are triple super phosphate and ammonium sulphate. }\end{array}$ & $\begin{array}{l}\text { Improve fertility with use of cover crops, } \\
\text { leguminous plants, compost making, farm yard } \\
\text { manure and planting shade trees. Other } \\
\text { permitted products can be used. }\end{array}$ \\
\hline
\end{tabular}

Notes: ${ }^{1}$ Differences in production practices are italicised for ease for reference. ${ }^{2}$ From Opoku-Ameyaw et al. (2010).

${ }^{3}$ AgroEco (undated). Field book: Organic and Fairtrade Cocoa AgroEco: www.agroeco.net.

Table 2. Definition of variables

\begin{tabular}{llll}
\hline & Variables & Definition & A priori expectation \\
\hline $\mathrm{a}$ & Gender & Male $=1$ and female $=0$ & Not applicable \\
$\mathrm{b}$ & OUTPUT & Cocoa output in natural logs & Not applicable \\
$\mathrm{c}$ & FARMSIZE & Area cultivated in natural logs & + \\
$\mathrm{d}$ & LABOUR & Total labour employed in natural logs & \\
$\mathrm{e}$ & FARM AGE & Years since cocoa farm was planted till 2014 &,+- \\
$\mathrm{f}$ & Adoption of organic production $($ ORGANIC) & Organic=1 and zero otherwise &,-+ \\
$\mathrm{g}$ & STATUS & Owner =1, Otherwise=0 &,+- \\
$\mathrm{h}$ & Usefulness of extension advice $($ EXTNUSE) & Yes=1, no=0 & - \\
$\mathrm{i}$ & Cocoa farming experience $(F A R M E X P)$ & How long farmer cultivated cocoa in years &,+- \\
$\mathrm{j}$ & Age of farmer $(A G E F)$ & Age of farmer measured in years & - \\
$\mathrm{k}$ & Education $(E D U C)$ & Years spent in formal education system & + \\
$\mathrm{l}$ & Household size $(H H S)$ & Number of persons living in household & + \\
$\mathrm{m}$ & Farmer-Based organisation membership $(F B O)$ & Member of farm association=1 & - \\
& & $0=$ otherwise &,+- \\
$\mathrm{n}$ & Cocoa Swollen Shoot Virus Disease attack $(C S S V D)$ & Yes=1, No=0 & + \\
o & Access to credit $(C R E D A C C)$ & Yes $=1$, No $=0$ & + \\
\hline
\end{tabular}

According to the Cocoa Health and Extension Division (CHED) of the Ghana Cocoa Board, responsible also for extension services to cocoa farmers, there were 18,425 conventional cocoa farmers in the district. Based on these subpopulations, 278 and 378 organic and conventional farms respectively were randomly sampled. By aid of a questionnaire, data was collected on the sampled farms. The data was later segregated into male and female categories. In order to provide for nonresponse, few more samples elements were added to the 556. As a result, the usable questionnaires totalled 658 . The variables employed in the article are presented in Table 2.

\section{Model}

In order to determine efficiency, based on the Farrell (1957) definition, developing a frontier is a necessary condition. The frontier estimation approaches may be parametric and non-parametric. The most popular nonparametric approach is data envelopment analysis
(DEA), whilst the leading parametric approach is stochastic frontier analysis (SFA). SFA models are relevant as agriculture is inherently stochastic (Coelli, 1995; Ezeh, 2004). The SFA approach assumes a functional form of the frontier as well as a distribution of the composed error term. One of the elements in the composed error term is construed as technical inefficiency.

Estimation of technical efficiency with SFA involves estimating a production function with a composed error term (Aigner, et al., 1977; Meeusen and van den Broeck, 1977). The estimated inefficiencies are then regressed on variables considered to explain the technical inefficiency estimates. These two-stage estimation takes place as a as a one-step process. A typical production function is specified in matrix notation (Eq. 1).

$y=f(X, \beta) e^{\nu-u}$

where: 
$\boldsymbol{y}$ represents output, $\boldsymbol{X}$ is a vector of production inputs, including FARMSIZE, LABOUR, and FARMAGE. $\boldsymbol{\beta}$ is a vector of parameters to be estimated, $v$ and $u$ are error terms. The frontier production function is a measure of the maximum potential output obtainable. Both $v$ and $u$ cause actual production to deviate from this frontier. The random variable in the production that cannot be influenced by producers, represented by $v$, is identically and independently distributed (iid) as $N\left(0, \sigma^{2}\right.$ v). The nonnegative error term $u$ represents deviation from the maximum potential output attributable to technical inefficiency distributed as half-normal, which is independent of $v$. The stochastic terms $v$ and $u$ are assumed to be uncorrelated.

The technical inefficiency effects model may be specified in matrix notation (Eq. 2).

$u_{k}=Z \delta$

where:

$\boldsymbol{Z}$ is a vector of variables and $u_{k}$ is estimated technical inefficiencies. The $\boldsymbol{Z}$ are farm and farmer characteristics; variables $g$ to $o$ in Table 2. Equation 1 and 2 were estimated in a one-step procedure.

Two approaches have been employed to studying comparative analysis in technical efficiency for both conventional and organic agriculture and gender. Separate models for each technology have been estimated (Tzouvelekas et al., 2002a; 2002b; Karagiannias et al., 2006; Madau, 2007; Bayramoglu and Gundogmus, 2008; Sipiläinen et al., 2008; Charyulu and Biswas, 2010; Kramol et al., 2010; and Karagiannias et al., 2012). Both separate and metafrontier model estimations have also been accomplished (Madau, 2007, Sipiläinen et al., 2008; Kramol et al.,2010; Onumah et al., 2013). Metafrontier by design provide additional information beyond the separate frontier efficiencies and are useful in providing a common reference point for comparing efficiencies. However, the possibility of a metafrontier or stochastic metafrontier depends on the loglikelihood test which, would determine, if the data is amenable to modelling a metafrontier. In all cases, the SFA models were estimated.

\section{RESULTS AND DISCUSSIONS}

\section{Descriptive statistics}

Males and females differ statistically significantly on six variables; FARMSIZE, ORGANIC, EXTNUSE, EDUC, $F B O$ and $C S S V D$ (Table 3). Males on average, farmed more area of cocoa farm than females. This may be due to traditional norms that favour land holding among males than females. Also, more males practiced organic production relative to females. This is not surprising as Ragasa (2012) noted that, women have much slower observed rates of adoption of a wide range of technologies than men, due to differentiated access to complementary inputs and services. Females found extension advice from extension officers less useful than males did, just as females were less educated than males. This is consistent with UNESCO (2016) disparity in literacy rates in favour of males in Ghana, just as in many developing countries. Social norms in Ghana, tend to prefer males to females going to school although this has seen some change in recent times.

In agribusiness theory, FBOs are patron-owned (or user-owned) cooperatives, as opposed to investor-owned firms (Sykuta and Cook, 2001; Cook and Chaddad, 2004). In order to trigger the development of inclusive agribusiness that provides social and economic benefits to rural smallholders, promoting the commercial development of FBOs have become important (Francesconi and Wuoterse, 2015). In this light, FBO were used as means of cooperation and development in parts of Ghana including cocoa growing areas. This article found that, females had more farmer-based organisation membership than males. This may be explained by the fact that, females cooperate substantially more often while males cooperate substantially less often in groups (Charness and Rustichini, 2011). Indeed, men rely on an independent self-definition, whilst women an interdependent one (Cross and Madson, 1997; Markus and Kitayama, 1991). Therefore, females should have a higher tendency of group membership (FBO) than males.

Table 3. Gender-based mean difference test of variables

\begin{tabular}{llll}
\hline Variable & Female & Male & $t$ statistic \\
\hline OUTPUT & 5.1405 & 5.2324 & 1.3126 \\
FARMSIZE & 0.2940 & 0.4997 & $2.6126^{* * *}$ \\
LABOUR & 4.4213 & 4.5217 & 1.2209 \\
FARMAGE & 2.8529 & 2.9296 & -1.0245 \\
ORGANIC & 0.3267 & 0.4434 & $-2.2700^{* * *}$ \\
STATUS & 1.8416 & 1.8133 & 0.3292 \\
EXTNUSE & 2.7030 & 3.0180 & $2.7208^{* * *}$ \\
FARMEXP & 16.9901 & 17.9300 & -0.7599 \\
AGEF & 49.5347 & 48.5637 & 0.7046 \\
EDUC & 7.5248 & 8.7990 & $-3.3608 * * *$ \\
HHS & 6.0693 & 6.4749 & -1.0975 \\
FBO & 1.6535 & 1.1293 & $3.1005^{* * *}$ \\
CSSVD & 0.1584 & 0.2621 & $-2.5293^{* * *}$ \\
CREDACC & 0.3168 & 0.3214 & -0.0896 \\
\hline NOte: & $*$
\end{tabular}

Note: 1. *,**,*** implies 10\%, 5\% and $1 \%$ levels of significance respectively.

\section{Model selection}

For the male group, the loglikelihood ratio (LR) test shows that, null hypothesis that the Cobb-Douglas OLS is the preferred functional form is rejected in favour of the Cobb-Douglas stochastic frontier (Table 4). For the translog, the stochastic frontier is a better representation of the data based on the LR test than the translog OLS. The third pane of Table 4 shows the comparison of the Cobb-Douglas and translog production functions. The LR test statistics of 92.9500 means that, the null hypothesis that the Cobb-Douglas stochastic frontier model is a better representation of the data is rejected in favour of the translog.

In respect of the female group, the stochastic CobbDouglas production function is preferred to the mean estimation, OLS function. Similarly, the LR test of 18.007 means that, the translog stochastic frontier is preferred to the OLS translog. Turning to the third pane, 
the LR test statistics is 9.277. The null hypothesis that the Cobb-Douglas is a better representation of the data cannot be rejected. Therefore, for males, translog functional forms is selected whilst the Cobb-Douglas is selected for females. Following from the non-conformity of the production functional forms, the metafrontier could not be estimated.

Table 4. Hypothesis tests models based on gender

\begin{tabular}{|c|c|c|}
\hline & Male & Female \\
\hline $\mathrm{OLS}_{\mathrm{CB}}$ & -658.2620 & -82.7367 \\
\hline $\mathrm{SFA}_{\mathrm{CB}}$ & -634.9593 & -69.9021 \\
\hline LR & $46.6053 * * *$ & $25.6692 * * *$ \\
\hline Decision & Reject & Reject \\
\hline $\mathrm{OLS}_{\mathrm{TL}}$ & -612.0846 & -74.2661 \\
\hline $\mathrm{SFA}_{\mathrm{TL}}$ & -588.4843 & -65.2636 \\
\hline LR & $47.2005 * * *$ & $18.0070 *$ \\
\hline Decision & Reject & Reject \\
\hline $\mathrm{SFA}_{\mathrm{CB}}$ & -634.9593 & -69.9021 \\
\hline $\mathrm{SFA}_{\mathrm{TL}}$ & -588.4843 & -65.2636 \\
\hline LR & $92.9500 * * *$ & 9.277 \\
\hline Decision & Reject & Accept \\
\hline
\end{tabular}

Note: 1. *,**,*** implies $10 \%, 5 \%$ and $1 \%$ levels of significance respectively.

\section{Comparisons of technical efficiencies}

The results from Table 5 show that, females are closer to their group frontier than males are; 0.8925 and 0.7306 respectively. A Student's $t$ test of the means produced a statistic of 8.8264 , statistically significantly different from zero at $1 \%$ level of probability. Since the reference points for measuring the technical efficiencies are different, a common reference such as metafrontier would have been desirable. Unfortunately, this could not be estimated as stated earlier. Nevertheless, females can increase output by $11 \%$ without using additional input whilst males, without additional input, can increase output by more than twice of the margin of females $(26 \%)$.

The second pane of Table 5 shows the differences in technical efficiencies between organic and conventional producers who are males. The mean of conventional producers is 0.7607 as opposed to organic producers of 0.6929 . The mean difference of 0.0679 is statistically significant at $1 \%$ level of probability $(t=6.0973)$. This implies that, conventional male cocoa producers are more technically efficient than organic male cocoa producers. Unrestricted access to productive inputs may have accounted for this. This finding for sex is consistent with both conventional and organic cocoa study of Onumah et al. (2013). Other studies whose conclusions are consistent with this article's findings are Tzouvelekas $\boldsymbol{e t}$ al. (2001), Arandia and Aldanondo-Ochoa (2008), Oude Lansink et al. (2002) and Poudel et al. (2011).

In the case of females, the conventional producers are also closer to the female frontier (0.9049) than organic producers $(0.8670)$. Although, there is apparent difference in these means (0.0379), the Student's $t$ statistic of 0.9026 has probability greater than $10 \%$. Thus, the apparent difference may be by chance. Due to differentiated access to complementary inputs and services, there is unlikely to be differences among females in technology adoption (Ragasa, 2012). The conclusion of a non-cocoa study of Mayen et al. (2010), is consistent with the findings of this article.

Another important dimension of the gender analysis was to compare male and female farmers within each production category. Table 6 shows that, for conventional producers, females are closer to the frontier than males; 0.9049 as against 0.7607 . The mean difference of 0.1442 is statistically significant at $1 \%$ level of probability. In the case of organic cocoa producers, females registered mean technical efficiency of 0.8670 whilst males posted 0.6929. The difference between these means; 0.1741 is statistically significant at $0.00 \%$ level of probability. From the forgoing, females are definitely more technically efficient than males. This finding contrasts with the conclusion of Takalign et al. (undated) who found that male-headed crops production households in Wolaita zone in Ethiopia were more technical efficient than females.

Table 5. Comparison of efficiencies based on gender

\begin{tabular}{|c|c|c|c|c|c|}
\hline Group & Observations & Mean & $\begin{array}{l}\text { Standard. } \\
\text { Error }\end{array}$ & $\begin{array}{l}\text { Standard } \\
\text { Deviation }\end{array}$ & $t$ \\
\hline \multicolumn{6}{|c|}{ Efficiency based on gender onl $y^{1,2}$} \\
\hline Female & 101 & 0.8925 & 0.0175 & 0.1738 & \\
\hline Male & 557 & 0.7396 & 0.0055 & 0.1299 & \\
\hline Combined & 658 & 0.7555 & 0.0058 & 0.1496 & \\
\hline Difference & & 0.1619 & 0.0183 & & $8.8264 * * *$ \\
\hline \multicolumn{6}{|c|}{ Males efficiencies based on technology } \\
\hline Conventional & 310 & 0.7607 & 0.0059 & 0.1036 & \\
\hline Organic & 247 & 0.6929 & 0.0095 & 0.1485 & \\
\hline Combined & 557 & 0.7306 & 0.0055 & 0.1299 & \\
\hline Difference & & 0.0679 & 0.0111 & & $6.0973 * * *$ \\
\hline \multicolumn{6}{|c|}{ Females efficiencies based on technology } \\
\hline Conventional & 68 & 0.9049 & 0.0185 & 0.1524 & \\
\hline Organic & 33 & 0.8670 & 0.0377 & 0.0377 & \\
\hline Combined & 101 & 0.8925 & 0.0175 & 0.1758 & \\
\hline Difference & & 0.0379 & 0.0420 & & 0.9026 \\
\hline
\end{tabular}

Notes: ${ }^{1}$ Two-sample $t$ test with unequal variance. ${ }^{2} * * *$-statistical significance at $1 \%$ level of significance. 
Table 6. Comparison of mean of gender within each production technology

\begin{tabular}{lcrrrr}
\hline & Observations & Mean & Standard Error & Standard Deviation & $t$ - test \\
\hline Female & 68 & 0.9049 & 0.0185 & 0.1524 & \\
Male & 310 & 0.7607 & 0.0059 & 0.1036 & $7.4337 * * *$ \\
Combined & 378 & 0.7867 & 0.0065 & 0.1265 & \\
Differences & & 0.1442 & & & \\
& & & Organic & & \\
Female & 33 & 0.8670 & 0.0377 & 0.1485 & \\
Male & 247 & 0.6929 & 0.0095 & & \\
Combined & 280 & 0.7867 & 0.0100 & & \\
Differences & & 0.1741 & 0.0389 & & \\
\hline
\end{tabular}

Notes: ${ }^{1}$ Two-sample t test with unequal variance. ${ }^{2 * * *}$-statistical significance at $1 \%$ level of significance.

\section{Discussion of selected models}

The marginal productivities are presented in Table 7. Inclusion of fertiliser and pesticides variables resulted in non-convergence of the iteration. This arose from the fact that these inputs were freely supplied to farmers based land area farmed. Thus, there was correlation between these and FARMSIZE. The limitation of the inputs to these three may raise concerns about endogeneity. All the marginal productivities are positive except FARMAGE for females. Gimbol et al. (1994) noted that, cocoa trees start producing at a certain age after planting, reach a maximum and remain fairly constant for some years, then start declining. Currey et al. (2007) specifically showed that, the early stage is less than 3 years (immature), the second stage; mature (3-8 years) and the third stage is senile (7-8 years and above). Thus, depending on the age of trees, cocoa output and time (age) may be negatively or positively related to output. Since the growth curve of cocoa is not entirely linear, the marginal productivity of FARMAGE could be negative or positive.

All elasticities of the translog (male) model are inelastic as the Cobb-Douglas (female) model. Both genders showed decreasing returns-to-scale although females show higher slightly higher RTS than males. This result confirm the higher productivity of females than males.

\section{Discussion of selected models}

The marginal productivities are presented in Table 7 . Inclusion of fertiliser and pesticides variables resulted in non-convergence of the iteration. This arose from the fact that these inputs were freely supplied to farmers based land area farmed. Thus, there was correlation between these and FARMSIZE. The limitation of the inputs to these three may raise concerns about endogeneity. All the marginal productivities are positive except FARMAGE for females. Gimbol et al. (1994) noted that, cocoa trees start producing at a certain age after planting, reach a maximum and remain fairly constant for some years, then start declining. Currey et al. (2007) specifically showed that, the early stage is less than 3 years (immature), the second stage; mature (3-8 years) and the third stage is senile (7-8 years and above). Thus, depending on the age of trees, cocoa output and time (age) may be negatively or positively related to output. Since the growth curve of cocoa is not entirely linear, the marginal productivity of FARMAGE could be negative or positive.

All elasticities of the translog (male) model are inelastic as the Cobb-Douglas (female) model. Both genders showed decreasing returns-to-scale although females show higher slightly higher RTS than males. This result confirm the higher productivity of females than males.

The selected models are presented in Table 8 . The coefficients of FARMEXP and CSSVD are both negative and statistically significant for the female and male models. This means that, more experience in cocoa farming enhances technical efficiency of cocoa production among both males and females. The incidence of disease (CSSVD) on cocoa farms reduces yield hence discourages optimisation of output. Thus, the coefficient of CSSVD is positive and statistically significant. As FARMEXP improves cocoa farmers build on the skills and capabilities to effectively combine farm resources to increase actual output thereby enhancing efficiency. This results suggest early introduction of cocoa farming to would-be cocoa farmers. For example, means that students of second cycle schools and adults in cocoa growing areas should be introduced to cocoa farming early.

CSSVD, which is caused by Cacao swollen shoot virus (CSSV) (of genus Badnavirus (Lot et al., 1991); family Badnaviridae), is one of the most devastating scourges of cocoa that, in the 1940s, threatened to wipe out the cocoa industry in what is now Ghana (DzahiniObiatey et al., 2006). The disease results in loss of trees and consequently loss of yield. Although the control methods involve cutting and burning of affected trees (Owusu, 1983; Thresh et al., 1988a; Opoku-Ameyaw et al., 2010), the loss of yield and delay in obtaining harvest from newly planted trees lead to decrease in output given the productive resources employed thereby, exacerbating technical inefficiency. Given the effect of CSSVD on technical inefficiency, in spite of the control methods, breeding disease resistant or disease tolerant cultivars is necessary.

Although the coefficients of $F B O$ are negative for both models, only the magnitudes of the female model is statistically significant. It will be recalled that, in Table 2, females differed significantly from males in $F B O$ membership. Thus, belonging to farmer-based organisations enhances efficiency among females. For females, FBOs provide networking opportunities; 
possibly augmenting or substituting for extension support, which have contributed to enhancing observed output.

Table 7. Marginal productivities of inputs

\begin{tabular}{lcc}
\hline & Translog & Cobb-Douglas \\
\hline & Males & Females \\
FARMSIZE & 0.08889 & 0.3213 \\
LABOUR & 0.3210 & 0.4146 \\
FARMAGE & -0.0844 & -0.2464 \\
Returns-to-scale & 0.3254 & 0.4895 \\
\hline
\end{tabular}

Table 8. Estimations of gender groups

\begin{tabular}{|c|c|c|}
\hline & Males & Females \\
\hline FARMSIZE & $\begin{array}{r}0.6073 * * \\
(0.2626)\end{array}$ & $\begin{array}{r}0.3213 * * * \\
(0.1056)\end{array}$ \\
\hline$L A B O U R$ & $\begin{array}{r}2.0272 * * * \\
(0.3679)\end{array}$ & $\begin{array}{r}0.4146 * * * \\
(0.0702)\end{array}$ \\
\hline FARMAGE & $\begin{array}{r}2.1196 * * * \\
(0.4621)\end{array}$ & $\begin{array}{r}-0.2464 * * \\
(0.1210)\end{array}$ \\
\hline FARMSIZE $^{2}$ & $\begin{array}{r}0.0366 * * * \\
(0.0049)\end{array}$ & - \\
\hline$L A B O U R^{2}$ & $\begin{array}{r}-0.1570 * * * \\
(0.0349)\end{array}$ & - \\
\hline FARMAGE $E^{2}$ & $\begin{array}{r}-0.2776 * * * \\
(0.0591)\end{array}$ & - \\
\hline FARM SIZE* LABOUR & $\begin{array}{r}-0.1546 \\
(0.0992)\end{array}$ & - \\
\hline FARM SIZE*FARMAGE & $\begin{array}{r}0.0554 \\
(0.0929)\end{array}$ & - \\
\hline$L A B O U R * A G E$ & $\begin{array}{r}-0.3137 * * \\
(0.1238)\end{array}$ & - \\
\hline CONSTANT & $\begin{array}{r}-2.1486^{*} \\
(1.2076)\end{array}$ & $\begin{array}{r}4.0713 * * * \\
(0.4797)\end{array}$ \\
\hline STATUS & $\begin{array}{r}-0.4658^{*} \\
(0.2506)\end{array}$ & $\begin{array}{r}-0.0759 \\
(0.7107)\end{array}$ \\
\hline EXTNUSE & $\begin{array}{r}0.3719 \\
(0.2264)\end{array}$ & $\begin{array}{r}0.7672 \\
(0.8387)\end{array}$ \\
\hline FARMEXP & $\begin{array}{r}-0.0605^{* *} \\
(0.0301)\end{array}$ & $\begin{array}{c}-0.2218^{*} \\
(0.1315)\end{array}$ \\
\hline$A G E F$ & $\begin{array}{r}-0.0304 \\
(0.0194)\end{array}$ & $\begin{array}{r}-0.1189 \\
(0.1145)\end{array}$ \\
\hline$E D U C$ & $\begin{array}{r}0.0179 \\
(0.0553)\end{array}$ & $\begin{array}{r}0.1312 \\
(0.2587)\end{array}$ \\
\hline$H H S$ & $\begin{array}{r}-0.0461 \\
(0.0650)\end{array}$ & $\begin{array}{r}0.0310 \\
(0.2103)\end{array}$ \\
\hline$F B O$ & $\begin{array}{r}-0.1245 \\
(0.2309)\end{array}$ & $\begin{array}{r}-7.0274 * * \\
(3.3005)\end{array}$ \\
\hline CSSVD & $\begin{array}{r}0.8771 * * \\
(0.3918)\end{array}$ & $\begin{array}{r}4.9670 * * \\
(2.3259)\end{array}$ \\
\hline CREDACC & $\begin{array}{r}0.2891 \\
(0.3304)\end{array}$ & $\begin{array}{r}-0.2204 \\
(1.6603)\end{array}$ \\
\hline Constant & $\begin{array}{r}0.3815 \\
(1.2874)\end{array}$ & $\begin{array}{r}6.1100 \\
(6.8308)\end{array}$ \\
\hline sigma_v & $\begin{array}{r}0.6385 \\
(0.0315)\end{array}$ & $\begin{array}{r}0.4542 \\
(0.0356)\end{array}$ \\
\hline $\operatorname{lnsig} 2 \mathrm{v}$ & $\begin{array}{r}-0.8973 * * * \\
(0.0987)\end{array}$ & $\begin{array}{r}-1.5784 * * * \\
(0.1565)\end{array}$ \\
\hline Number of observations & 557 & 101 \\
\hline Wald & $132.38 * * *$ & $44.15^{* * *}$ \\
\hline Log likelihood & -588.4843 & -69.9021 \\
\hline
\end{tabular}

Note: $* * *, * * *$ implies $10 \%, 5 \%$ and $1 \%$ levels of significance respectively.

As for $F B O$, the sign of the coefficients for STATUS are negative. However, in this case, the coefficients for males is statistically significant. This suggests that, male cocoa farmers would have to manage their own farms if they wish to reduce inefficiency.

\section{CONCLUSIONS AND RECOMMENDATIONS}

This article provided a gender perspective to organicconventional technical efficiency comparative studies; a key contribution to the pertinent literature as well as contributing to the conventional organic agriculture efficiency debate. Data from 280 organic and 378 conventional cocoa farmers from Suhum area in Ghana; segregated into 101 females and 557 males were analysed. Although, metafrontier is useful in comparative analyses of this nature, the data did not permit estimating metafrontier. On the contrary, separate frontiers were estimated for males and females. The article found gender disparity with respect to farm size, usefulness of extension advice, farmer-based organisation membership, adoption of organic technology, years of formal education and disease incidence. Whilst the first three are in favour of females, the last three are in favour of males. The frontier analyses showed that, females are more technically efficient than males irrespective of technology; conventional or organic, although males tended to be more productive. Conventional producers are more technically efficient than organic producers. Whilst cocoa farming experience improved technical efficiency, disease incidence reduced technical efficiency. Membership of farmer-based organisation reduced technical inefficiency among females but was ineffective among males.

Based on these findings, the following recommendations are apt. There is the need for increased access of females to productive inputs and to education. Farmer-based organisations should be used as avenues for extension service provision. Organic cocoa farmers need more efficiency enhancing resources. Male farmers should endeavour to manage their own cocoa farms as caretakers did not improve efficiency of their farms. There is the need for early introduction of cocoa farming to would-be farmers. Greater efforts at controlling CSSVD as well as breeding disease resistant cultivars of cocoa is also recommended. Further gender-based studies for other products for organic-conventional production is recommended.

\section{REFERENCES}

AGROECO undated: Field book: Organic and Fairtrade Cocoa AgroEco: www.agroeco.net.

AIGNER, D., LOVELL, C. A. L., \& SCHMIDT, P. (1977). Formulation and estimation of stochastic frontier production function models. Journal of econometrics, 6(1): 21-37. DOI: $10.1016 / 0304-$ 4076(77)90052-5

ARANDIA, A., AND ALDANONDO-OCHOA, A. (2008). Social versus private efficiency: A comparison of conventional and organic farming systems in vineyard production. In 2008 International Congress, August 26 29, 2008, Ghent, Belgium No. 44416. European Association of Agricultural Economists. 
AYENOR, G.K., RÖLING, N.G., PADI, B., VAN HUIS, A., OBENG-OFORI, D., \& ATENGDEM, P.B. (2004). Converging farmers' and scientists' perspectives on researchable constraints on organic cocoa production in Ghana: results of a diagnostic study. NJAS-Wageningen Journal of Life Sciences, 52(3): 261-284. DOI:10.1016/S1573-5214(04)80017-4

BAYRAMOGLU, Z., \& GUNDOGMUS, E. (2008). Cost efficiency on organic farming: A comparison between organic and conventional raisin-producing households in Turkey. Spanish Journal of Agricultural Research, 6(1): 3-11. DOI: 10.5424/sjar/2008061-289

BELTRAN-ESTEVE, M., REIG-MARTÍNEZ, E., \& ESTRUCH-GUITART, V. (2015). Assessing conventional and organic citrus farming systems ecoefficiency: a metafrontier directional distance function approach using Life Cycle Analysis. Working Papers in Applied Economics. WPAE-2015-01. Universitat de València. ISSN 2172-3036, 27 pp. ftp://147.156.210.157/RePEc/pdf/eec_1501.pdf

BEST, H. (2010). Environmental concern and the adoption of organic agriculture. Society and Natural Resources: An International Journal, 23(5): 451-468. DOI: http://dx.doi.org/10.1080/08941920802178206

CHARNESS, G., \& RUSTICHINI, A. (2011). Gender differences in cooperation with group membership. Games and Economic Behaviour, 72(1): 77-85. DOI: $10.1016 /$ j.geb.2010.07.006

CHARYULU, D. K. AND BISWAS, S. (2010). Economics and efficiency of organic farming vis-à-vis conventional farming in India. Indian Institute of Management Ahmedabad-380 015, India. W.P. No. 2010-04-03, April 2010.

COELLI, T.J. (1995). Estimators and hypothesis tests for a stochastic frontier function: A Monte Carlo analysis. Journal of Productivity Analysis, 6: 247-268. DOI: 10.1007/BF01076978

COOK, M.L. \& CHADDAD, F.R. (2004). Redesigning Cooperative Boundaries: The Emergence of New Models. American Journal of Agricultural Economics, 86(5): 1249-53. DOI: https://doi.org/10.1111/j.00029092.2004.00673.x

CROSS, S. E., \& MADSON, L. (1997). Models of the self: self-construals and gender. Psychological Bulletin, 122(1): 5. DOI: http://dx.doi.org/10.1037/00332909.122.1.5

DJOKOTO, J. G. (2015). Technical efficiency of organic agriculture: a quantitative review. Studies in Agricultural Economics, 117(2): 67-71.

http://dx.doi.org/10.7896/j.1512

DZAHINI-OBIATEY, H., AMEYAW, G. A., \& OLLENNU, L. A. (2006). Control of cocoa swollen shoot disease by eradicating infected trees in Ghana: A survey of treated and replanted areas. Crop Protection, 25(7):

647-652.

DOI:10.1016/j.cropro.2005.09.004

EZEH, C.I. (2004). A comparative study of fadama and non-fadama crop farmers in Osisioma-Ngwa L.G.A, Abia State Nigeria. Journal of Sustainable Tropical Agricultural Research, 11.

FARRELL, M. J. (1957). The measurement of productive efficiency. Journal of the Royal Statistical
Society, Series A (General) 120 (3): 253-290. DOI: $\underline{10.2307 / 2343100}$

FOOD AND AGRICULTURE ORGANISATION (1999). FAO position paper on Organic Agriculture. Available

at:

http://www.fao.org/docrep/meeting/X0075e.htm accessed July, 6, 2016, 21:00 GMT.

FRANCESCONI, G. N., \& WOUTERSE, F. (2015). The Health of Farmer-Based Organisations in Ghana: Organisational Diagnostics and Governance Implications. The Journal of Development Studies, 51(3): 262-273.

IFOAM (2014). The IFOAM NORMS for Organic Production and Processing Version 2014. ISBN978F3F944372F10F5,

http://www.ifoam.bio/sites/default/files/ifoam norms ve rsion july 2014.pdf

KARAGIANNIAS, G., SALHOFER, K., \& SINABELL, F. (2006). Technical efficiency of conventional and organic farms: some evidence for milk production. ÖGA Tagungsband, 2006, 3-4.

KARAGIANNIS, G., SALHOFER, K., \& SINABELL, F. (2012). Scale efficiency in organic and conventional dairy farming. Paper prepared for presentation at the 1st AIEAA Conference, 'Towards a Sustainable Bioeconomy: Economic Issues and Policy Challenges', 4-5 June, 2012, Trento, Italy.

KRAMOL, P., VILANO, R., FLEMING, E., \& KRISTIANSEN, P. (2010). Technical efficiency and technology gaps on 'clean and safe' vegetable farms in northern Thailand: A comparison of different technologies. Paper presented at the 54th National Conference of the Australian Agricultural and Resource Economics Society, Adelaide, Australia, $10-12$ February 2010.

LAKNER, S., \& BREUSTEDT, G. (2015). Efficiency analysis of organic farming systems-a review of methods, topics, results, and conclusions. In 2015 Conference, August 9-14, 2015, Milan, Italy (No. 212025). International Association of Agricultural Economists.

LAKNER, S., \& BREUSTEDT, G. (2016). Productivity and technical efficiency of organic farming-A literature survey. Acta Fytotechnica et Zootechnica, 18(5): 74-77. DOI: 10.15414/afz.2015.18.si.74-77

LOT, H., DJIEKPOR, E., \& JACQUEMOND, M. (1991). Characterization of the genome of cacao swollen shoot virus. Journal of General Virology, 72(7): 17351739. DOI: $\underline{\text { 10.1099/0022-1317-72-7-1735 }}$

MADAU, F. A. (2007). Technical efficiency in organic and conventional farming: Evidence from Italian cereal farms. Agricultural Economics Review, 8(1): 5-21.

MADER, P., FLIESSBACH, A., DUBOIS, D., GUNST, L., FRIED, P., \& NIGGLI, U. (2002). Soil fertility and biodiversity in organic farming. Science, 296(5573): 1694-1697. DOI: 10.1126/science.1071148

MARKUS, H. R., \& KITAYAMA, S. (1991). Culture and the self: Implications for cognition, emotion, and motivation. Psychological Review, 98(2): 224.DOI: 10.1037/0033-295X.98.2.224

MAYEN, C. D. BALAGTAS, J. V. AND ALEXANDER, C. E. (2010). Technology adoption and technical efficiency: Organic and conventional dairy 
farms in The United States. American Journal of Agricultural Economics 92: 181-195. DOI: https://doi.org/10.1093/ajae/aap018

MEEUSEN W., \& VAN DEN BROECK, J. (1977) Efficiency estimation from Cobb-Douglas production functions with composed error. International Economic Review, 18(2): 435-444. DOI: 10.2307/2525757

ONUMAH, J. A., ONUMAH, E. E., AL-HASSAN, R. M., \& BRÜMMER, B. (2013). Meta-frontier analysis of organic and conventional cocoa production in Ghana. Agricultural Economics-Czech 59(6): 271-280.

OPOKU-AMEYAW, K., BAAH, F., GYEDU-AKOTO, E., ANCHIRINAH, V., DZAHINI-OBIATEY, H. K., CUDJOE, A. R., AQUAYE, S., \& OPOKU, S. Y. (2010). Cocoa manual: A source book for sustainable cocoa production. Cocoa Research Institute of Ghana, New Tafo-Akim, Ghana.

OUDE LANSINK, A., PIETOLA, K. AND BÄCKMAN, S. (2002). Efficiency and productivity of conventional and organic farms in Finland 1994-1997. European Review of Agricultural Economics, 29: 51-65. DOI: https://doi.org/10.1093/erae/29.1.51

OWUSU, G. K. (1983). The cocoa swollen shoot disease problem in Ghana. Plant Virus Epidemiology (RT Plumb and JM Thresh, eds). Blackwell Scientific, Oxford, 7383.

POUDEL, K. L., YAMAMOTO, N. AND JOHNSON, T. G. (2011). Comparing technical efficiency of organic and conventional coffee farms in Nepal using data envelopment analysis DEA approach. In 85th Annual Conference of the Agricultural Economics Society.

SIPILÄINEN, T., MARKLUND, P-O., \& HUHTALA, A. (2008). Efficiency in agricultural production of biodiversity: Organic vs. conventional practices. Paper prepared for presentation at the 107th EAAE Seminar "Modeling of Agricultural and Rural Development Policies". Sevilla, Spain, January 29th - February 1st, 2008.

SYKUTA, M. E. \& COOK, M. (2001). A New Institutional Economics Approach to Contracts and Cooperatives. American Journal of Agricultural Economics, $83 \quad$ (5): $1273-1279 . \quad$ DOI: http://dx.doi.org/10.2139/ssrn.291189
HRESH, J. M., OWUSU, G. L. K., \& OLLENNU, L. A. A. (1988). Cocoa swollen shoot: an archetypal crowd disease. Zeitschrift für Pflanzenkrankheiten und Pflanzenschutz, 95(4): 428-446. URL: http://www.jstor.org/stable/43383326

TIEDEMANN, T. AND LATACZ-LOHMANN, W. (2012). Production risk and technical efficiency in organic and conventional agriculture - The case of arable farms in Germany. Journal of Agricultural Economics DOI: 10.1111/j.1477-9552.2012.00364.x.

TZOUVELEKAS, V., PANTZIOS, C. J. AND FOTOPOULOS, C. (2001). Economic efficiency in organic farming: Evidence from cotton farms in Viotia, Greece. Journal of Agricultural and Applied Economics, 33: $\quad 35-48$. DOI: $10.1017 / \mathrm{S} 1074070800020769$

TZOUVELEKAS, V., PANTZIOS, C. J., \& FOTOPOULUS, C. (2002a). Technical efficiency of alternative farming systems: the case of Greek organic and conventional olive-growing farms. Food Policy, 26 (6): 549-69. DOI: http://dx.doi.org/10.1016/S03069192(01)00007-0

TZOUVELEKAS, V., PANTZIOS, C. J., \& FOTOPOULOS, C. (2002b). Empirical evidence of technical efficiency levels in Greek organic and conventional farms. Agricultural Economics Review, 3(2): 49-60.

UNDP (1992): Benefits of diversity: An incentive towards sustainable agriculture. United Nations Development Programme, New York.

UNESCO (2016). UNESCO Institute for Statistics database. Available at: http://data.uis.unesco.org/Index.aspx?queryid=166 Accessed July 6, 2016.

WHO (2003). WHO definition of Health. Accessed on April, 12, 2012. Available at: http://www.who.int/about/definition/en/print.html.

YGL (2013). Information available from Yayra Glover Limited. http://yayraglover.com/ 